\title{
Effectiveness of Structured Teaching Program on Knowledge and Practice Regarding Care Bundle on Prevention of Ventila- tor-Associated Pneumonia among Nurses
}

\author{
Rakhi Mishra, MScN ${ }^{1^{*}}$ (D) and Navita Rani, MScN ${ }^{2}$ \\ ${ }^{1}$ Assistant Professor, College of Nursing, All India Institute of Medical Sciences, Rishikesh, Uttarakhand, India \\ ${ }^{2}$ M.Sc Nursing, Nightingale Institute of Nursing, Noida, India
}

*Corresponding author: Rakhi Mishra, MScN, Assistant Professor, College of Nursing, All India Institute of Medical Sciences, Rishikesh, Uttarakhand 249203, India, Tel: 951-3470-564

\begin{abstract}
Background: Ventilator-Associated pneumonia (VAP) is a major cause of morbidity and mortality and is the second most common nosocomial infection among critically ill patients, affecting $6 \%$ to $52 \%$ and can reach to $76 \%$ in some specific hospital settings. VAP can prolong the patient's length of stay in the hospital and thereby the financial burden. Knowledge and practice run parallel therefore, the present study was conducted to assess the effectiveness of structured teaching Program on knowledge and practice regarding care bundle on prevention of ventilator-associated pneumonia among nurses.
\end{abstract}

Materials and methods: Pre-experimental one group pretest and posttest design was adopted to accomplish the objectives. Non-probability convenience sampling technique was used to select the samples. The sample consists of 30 nurses working in the ICU of a tertiary care hospital, India. The pretest and post-test assessment of knowledge and practice of the nurses was carried out using the structured knowledge questionnaire and structured observational practice checklist. The obtained data were analyzed and interpreted using descriptive and inferential statistics.

Results: The mean pre-test knowledge and practice scores were 7.79 and 10.33 respectively. However, the post-test knowledge and practice scores were 24.1 and 17.16 that reveals improvement in knowledge and practice after administration of structured teaching program. The calculated t-test value was 14.95 and 16.72 for knowledge and practice which was highly significant at 0.05 level.

Conclusion: The study findings concluded that the Structured Teaching Program has improved the knowledge and practice of nurses regarding the care bundle on prevention of ventilator-associated pneumonia.

\section{Keywords}

Effectiveness, Structured teaching program, Knowledge, Practice, Ventilator associated pneumonia, Nurses

\section{Introduction}

Mechanical ventilation is a life-saving procedure, used for critically ill patients who are unable to breath spontaneously. However, patients on mechanical ventilation are susceptible to develop complications i.e. Ventilator-Associated Pneumonia (VAP). Incidence of VAP ranges from $5 \%$ to $67 \%$, with the highest rates seen among immuno compromised, surgical, and elderly patients [1,2]. The estimated risk of developing VAP is $1.5 \%$ per day and decreases to less than $0.5 \%$ per day after the $14^{\text {th }}$ day of mechanical ventilation. VAP increases the duration of hospitalization by 7 days and thereby the cost of health-care [1,3]. VAP is classified into early-onset (occurring $<5$ days) and late-onset (occurring $\geq$ 5 days) VAP after intubation [4]. VAP is oropharyngeal colonization of pathogens acquired through an exogenous source like infected hands and attire of health care professionals, contaminated respiratory instruments, intensive care environment, through hospital water or air. These pathogens reach the lung parenchyma and alter the host defense mechanism [5]. Pulmonary infection occurs due to the virulence of a pathogen, or break in the host defenses.

The infection control department plays a vital role

Citation: Mishra R, Rani N (2020) Effectiveness of Structured Teaching Program on Knowledge and Practice Regarding Care Bundle on Prevention of Ventilator-Associated Pneumonia among Nurses. Int Arch Nurs Health Care 6:149. doi.org/10.23937/2469-5823/1510149

Accepted: December 03, 2020: Published: December 05, 2020

Copyright: (C) 2020 Mishra R, et al. This is an open-access article distributed under the terms of the Creative Commons Attribution License, which permits unrestricted use, distribution, and reproduction in any medium, provided the original author and source are credited. 
in educating nurses on the prevention of VAP among intubated patients. Reduction in the incidence rate of VAP ultimately decreases the associated burden of illness. The Institute for Healthcare Improvement (IHI) recommended the practice of bundles, simple sets of evidence-based practices that, when performed collectively and reliably, have been proven to improve patient outcomes. The components of Ventilator Bundle include: i) Elevating head of the bed to 30-45 degree, ii) Daily 'sedation vacation' to assess readiness to extubate, iii) Peptic ulcer disease prophylaxis, iv) Deep venous thrombosis prophylaxis $[6,7]$.

Knowledgeable and skilled nurses are crucial in providing patient care, timely and correct decision minimizes the risks to patients. Several studies have reported the lack of knowledge regarding evidence-based strategies for preventing VAP among nurses [8-10]. Use of Structured Teaching Program on knowledge and practice regarding care bundle will help in preventing VAP, thus reducing the rate of morbidity significantly [11].

This study aimed to assess the effectiveness of structured teaching program on knowledge and practice regarding care bundle on prevention of ventilator-associated pneumonia among nurses working at tertiary care hospital.

\section{Methods}

The present study adopted pre-experimental one group pretest and posttest design to assess the effectiveness of structured teaching program on knowledge and practice regarding care bundle on prevention of Ventilator-Associated Pneumonia among nurses working at Intensive care unit of tertiary care hospital, India from $15^{\text {th }}$ Dec to $15^{\text {th }}$ Jan. Non-probability convenience sampling technique was used to select the samples. Thirty (30) Nurses working in Intensive care unit, available during the time of data collection and actively willing to participate were Included in the study. Those who didn't give their consent for participation and had already attended formal teaching program on Care Bundle on Prevention of Ventilator-Associated Pneumonia was excluded from this study.

\section{Sample size}

The sample size was calculated through Raosoft (2004), with a $5 \%$ margin of error and $95 \%$ confidence level from a population size of 40 . The calculated sample size was 37 . However, data was collected from 30 subjects as they met inclusion and exclusion criteria.

\section{Instruments}

Data were collected from participants under three sections. Section I - Socio-demographic characteristics. Section II - Structured knowledge questionnaire regarding Care Bundle on Prevention of Ventilator-Associated Pneumonia and Section III - Structured observational practice checklist regarding Care Bundle on Prevention of Ventilator-Associated Pneumonia.

Experts from nursing (04), medical (01), hospital administration (01) and microbiology (01) were involved in validation of questionnaire and reliability of Structured knowledge questionnaire was calculated with Spearman-Brown formula $(r=0.89)$ and reliability of observational practice checklist was calculated using inter-rater formula $(r=0.80)$.

The structured knowledge questionnaire consists of 30 multiple choice items from the following area- Causative organism, Route for VAP, Risk factors, Clinical findings, Infection control strategies, complications. Each correct answer scored one mark and the wrong answer zero. The total score was arbitrarily classified as Very good (25-30), Good (19-24), Average (13-18), Poor (712) and Very poor (0-6). The highest score was thirty and the lowest score was zero. Whereas, the Structured observational practice checklist had 20 items to assess nurses' practice regarding the care bundle on prevention of ventilator-associated pneumonia. The practice score was arbitrarily classified as Very good (16-20), Good (11-15), Average (6-10) and Poor (0-5). The highest score was twenty and the lowest score was zero.

The obtained data was analyzed using SPSS version 20. Mean and paired sample ' $\mathrm{t}$ ' test was calculated at 0.05 level of significance. The calculated $\boldsymbol{t}$ value more than the table value at 0.05 level was considered statistically significant. Fisher exact test was used to find association of knowledge and practice score with selected demographic variable at 0.05 level of significance. A $\boldsymbol{P}$ value less than 0.05 was considered statistically significant.

\section{Ethical consideration}

Ethical permission was obtained from the institutional ethics committee (letter No. 1128/NIN/PRI/FV/2017) and higher authorities of the tertiary care hospital. Participants were informed about the purpose of research and were ensured about the anonymity and confidentiality of the information. A written informed voluntary participation consent was taken from each study participant.

\section{Intervention}

Knowledge and Practice of Nurses working in Intensive care unit was assessed using structured knowledge questionnaire and structured observational practice checklist on Day-1. On the same day, A 45 minutes Structured Teaching Program on Prevention of Ventilator-Associated Pneumonia was implemented using PowerPoint presentation. The topics covered were: Definition, Incidence, Pathogenesis, Clinical manifestations, diagnostic evaluation, collaborative management and complications of VAP. The method of teaching was Lecture cum discussion. Post-test was conducted on Day-8 by administering same set of structured knowl- 
edge questionnaire and structured observational practice checklist.

\section{Results}

Table 1 shows that the majority 19 (64\%) of samples were less than 25 years of age. Most 22 (74\%) of them were females and had an Educational qualification level of B.Sc. Nursing 12 (40\%). Maximum 12 (40\%) samples had working experience of less than 1 year and between 1 to 3 years respectively. More than fifty percent of sample reported that they received information regarding care bundles on the prevention of VAP from Induction classes.

Table 2 shows that the Majority (57\%) of samples

Table 1: Distribution of samples in terms of Socio-Demographic Characteristics $(\mathrm{N}=30)$.

\begin{tabular}{|c|c|c|}
\hline $\begin{array}{l}\text { Socio-Demographic } \\
\text { Characteristics }\end{array}$ & Frequency & $\begin{array}{l}\text { Percentage } \\
(\%)\end{array}$ \\
\hline \multicolumn{3}{|l|}{ Age in years } \\
\hline a) Less than 25 & 19 & 64 \\
\hline b) $25-35$ & 10 & 32 \\
\hline c) Above 35 & 01 & 04 \\
\hline \multicolumn{3}{|l|}{ Gender } \\
\hline a) Male & 08 & 26 \\
\hline b) Female & 22 & 74 \\
\hline \multicolumn{3}{|l|}{ Educational qualification } \\
\hline a) G.N.M & 09 & 30 \\
\hline b) B.Sc. Nursing & 12 & 40 \\
\hline c) Post Basic B.Sc. Nursing & 06 & 20 \\
\hline d) M.Sc. Nursing & 03 & 10 \\
\hline \multicolumn{3}{|l|}{ Years of clinical experience } \\
\hline a) Less than1year & 12 & 40 \\
\hline b) 1-3 year & 12 & 40 \\
\hline c) Above 3 year & 06 & 20 \\
\hline \multicolumn{3}{|l|}{$\begin{array}{l}\text { Other Source of information } \\
\text { regarding care bundle on } \\
\text { prevention of VAP }\end{array}$} \\
\hline $\begin{array}{l}\text { a) Continuing Nursing } \\
\text { Education }\end{array}$ & 08 & 26 \\
\hline b) Library & 17 & 57 \\
\hline c) Induction classes & & \\
\hline
\end{tabular}

Table 2: Knowledge score of nurses regarding the care bundle on $\operatorname{VAP}(\mathrm{N}=30)$.

\begin{tabular}{|c|c|c|c|c|}
\hline \multirow{2}{*}{$\begin{array}{l}\text { Knowledge } \\
\text { Score }\end{array}$} & \multirow[t]{2}{*}{ Category } & Pre-test & Post-test & t Value \\
\hline & & n (\%) & n (\%) & \multirow{7}{*}{14.95} \\
\hline $0-6$ & Very poor & $00(00)$ & $00(00)$ & \\
\hline $7-12$ & Poor & $06(20)$ & $00(00)$ & \\
\hline $13-18$ & Average & $17(57)$ & $00(00)$ & \\
\hline $19-24$ & Good & $07(23)$ & $17(57)$ & \\
\hline $25-30$ & Very good & $00(00)$ & $13(43)$ & \\
\hline \multicolumn{2}{|l|}{ Mean } & 7.79 & 24.1 & \\
\hline
\end{tabular}

Paired $\mathrm{t}$ test applied, $\mathrm{p}$ value $>0.05$ level is statistically significant, Df $(29)=2.04$. scored between 13-18 in Pre-test. However, in the posttest, the majority (57\%) of samples scored between 1924. Thereby, indicating an improvement in Knowledge score after implementation of a structured teaching program on care bundle regarding VAP. Data also depicts that mean pre-test and post-test Knowledge score was 7.79 and 24.1 respectively. The calculated ' $t$ ' value was 14.95 that indicates a significant difference between mean pre and post-test knowledge scores.

Table 3 depicts the Majority (53\%) of samples scored between 6-10 in the Pre-test. However, in the Post-

Table 3: Practice score of nurses regarding the care bundle on $\operatorname{VAP}(\mathrm{N}=30)$.

\begin{tabular}{|l|l|l|l|l|}
\hline $\begin{array}{l}\text { Practice } \\
\text { Score }\end{array}$ & Category & Pre-test & Post-test & t Value \\
\cline { 1 - 3 } & & $\mathbf{n}(\%)$ & $\mathbf{n}(\mathbf{\%})$ & \\
\hline $0-5$ & Poor & $00(00)$ & $00(00)$ & \\
\hline $6-10$ & Average & $16(53)$ & $00(00)$ & \multirow{2}{*}{16.72} \\
\hline $11-15$ & Good & $14(47)$ & $05(17)$ & \\
\hline $16-20$ & Very good & $00(00)$ & $25(83)$ & \\
\hline Mean & & 10.33 & 17.16 & \\
\hline
\end{tabular}

Paired $t$ test was used, $p$ value $>0.05$ level is statistically significant, Df $(29)=2.04$.

Table 4: Association of Knowledge score regarding care bundle on VAP with Selected Socio-Demographic Characteristics ( $\mathrm{N}=$ 30).

\begin{tabular}{|c|c|c|c|}
\hline $\begin{array}{l}\text { Socio-Demographic } \\
\text { Characteristics }\end{array}$ & $\begin{array}{l}\text { Below } \\
\text { mean }\end{array}$ & $\begin{array}{l}\text { Above } \\
\text { mean }\end{array}$ & $\begin{array}{l}\text { Fisher } \\
\text { Exact test } \\
\text { P value }\end{array}$ \\
\hline $\begin{array}{l}\text { Age in years } \\
\begin{array}{l}\text { a) Less than } 25 \mathrm{yr} \\
\text { b) } 25-35 \mathrm{yr} \\
\text { c) Above } 35 \mathrm{yr}\end{array}\end{array}$ & $\begin{array}{l}9 \\
6 \\
1\end{array}$ & $\begin{array}{l}10 \\
4 \\
0\end{array}$ & 0.17 \\
\hline $\begin{array}{l}\text { Gender } \\
\begin{array}{l}\text { a) Male } \\
\text { b) Female }\end{array}\end{array}$ & $\begin{array}{l}3 \\
5\end{array}$ & $\begin{array}{l}11 \\
11\end{array}$ & 0.39 \\
\hline 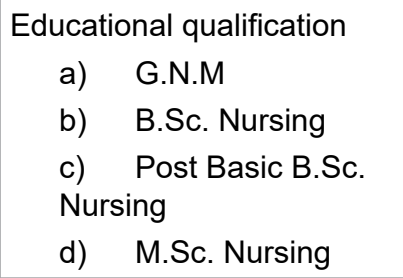 & $\begin{array}{l}5 \\
4 \\
3 \\
2\end{array}$ & $\begin{array}{l}4 \\
8 \\
3 \\
1\end{array}$ & 5.44 \\
\hline $\begin{array}{l}\text { Years of clinical experience } \\
\text { a) Less than } 1 \text { year } \\
\text { b) } 1-3 \text { year } \\
\text { c) Above } 3 \text { year }\end{array}$ & $\begin{array}{l}7 \\
5 \\
2\end{array}$ & $\begin{array}{l}5 \\
7 \\
4\end{array}$ & 0.09 \\
\hline $\begin{array}{l}\text { Other Source of information } \\
\text { regarding care bundle on } \\
\text { prevention of VAP } \\
\text { a) Continuing Nursing } \\
\text { Education } \\
\text { b) Library } \\
\text { c) Induction classes }\end{array}$ & $\begin{array}{l}2 \\
2 \\
10\end{array}$ & $\begin{array}{l}3 \\
6 \\
7\end{array}$ & 0.35 \\
\hline
\end{tabular}

Fisher Exact test applied, $\mathrm{P}$ value $<0.05$ is statistically significant. 
test Majority (83\%) of samples scored between 16-20. Thereby, indicating an improvement in practice score after a structured teaching program on care bundle regarding VAP. Data also depicts that mean pre-test and post-test practice score was 10.33 and 17.16 respectively. The calculated ' $\mathrm{t}$ ' value was 16.72 that shows a significant difference between mean pre and post-test scores.

Data in Table 4 revealed no significant association between Knowledge score regarding care bundle on VAP with selected Socio-Demographic Characteristics at 0.05 level of significance.

Data represented in Table 5 shows that there is no significant association between Practice score regarding care bundle on VAP with Selected Socio-Demographic Characteristics at 0.05 level of significance.

\section{Discussion}

The present study was conducted to assess the effectiveness of structured teaching Program on knowledge and practice regarding care bundle on prevention of ventilator-associated pneumonia among nurses working at Intensive care unit of selected tertiary care Hospital, Noida. The findings of the present study are discussed according to the study objectives and results

Table 5: Association of Practice score regarding care bundle on VAP with Selected Socio-Demographic Characteristics (N $=30$ ).

\begin{tabular}{|c|l|l|l|}
\hline $\begin{array}{l}\text { Socio-Demographic } \\
\text { Characteristics }\end{array}$ & $\begin{array}{l}\text { Below } \\
\text { mean }\end{array}$ & $\begin{array}{l}\text { Above } \\
\text { mean }\end{array}$ & P-value \\
\hline $\begin{array}{c}\text { Age in years } \\
\text { a) Less than 25 yr }\end{array}$ & 17 & 2 & \\
b) 25-35 yr & 10 & 0 & 0.39 \\
c) Above 35 yr & 1 & 0 & \\
\hline $\begin{array}{c}\text { Gender } \\
\text { a) Male }\end{array}$ & 8 & 0 & 0.53 \\
b) Female & 20 & 2 & \\
\hline $\begin{array}{c}\text { Educational qualification } \\
\text { a) G.N.M }\end{array}$ & 9 & 0 & \\
b) B.Sc. Nursing & 11 & 1 & 0.48 \\
c) Post Basic B.Sc. Nursing & 5 & 1 & \\
d) M.Sc. Nursing & 3 & 0 & \\
\hline Years of clinical experience & & & \\
a) Less than 1 year & 10 & 2 & \\
b) 1-3 year & 12 & 0 & 0.15 \\
\hline c) Above 3 year & 6 & 0 & \\
\hline $\begin{array}{l}\text { Other Source of information } \\
\text { regarding care bundle on } \\
\text { prevention of VAP }\end{array}$ & & & \\
a) Continuing Nursing & 5 & 0 & \\
\hline $\begin{array}{l}\text { b) Library } \\
\text { c) Induction classes }\end{array}$ & 15 & 2 & \\
\hline
\end{tabular}

Fisher Exact test applied, $\mathrm{P}$ value $<0.05$ is statistically significant. of other studies. VAP is a leading cause of morbidity and mortality among critically ill patients and is aggravated by the underlying disease of the patient. VAP is a complication that develops after 48 hours following endotracheal intubation [12].

The incidence rate of VAP among mechanically ventilated patients is $28 \%$, and may vary with the duration of mechanical ventilation. It is estimated that per day $3 \%$ of the cases occur during the first 5 days, 2\% during 6-10 days, and $1 \%$ after 10 days [13]. VAP is regarded as the second most common cause of nosocomial infection next to urinary tract infection [14]. Nurses working in the critical care unit play a significant role in managing patients on a ventilator. A study conducted by Busi S, et al., reported that $21(96.6 \%)$ nurses had inadequate knowledge and 21 (96.6\%) had Inadequate Practice scores on prevention of VAP before implementing structured teaching program regarding prevention of VAP. However, post-test scores show improvement in Knowledge and Practice i.e. 29 (96.6\%) had adequate knowledge and 29 (96.6\%) had adequate practice [15]. The findings were consistent with the present study findings where majority 17 (57\%) of samples had Average Knowledge score and Majority 16 (53\%) had average practice scores in Pre-test. However, in the post-test, the majority, 17 $(57 \%)$ of samples had a good knowledge score and 25 $(83 \%)$ scored very good in practice. Study conducted by Barsotti $E$, et al. to assess the knowledge of nurses regarding prevention of VAP reported that $22.6 \%$ of nurses had satisfactory knowledge and $54.8 \%$ had poor knowledge. The majority $(80.9 \%)$ of subjects revealed application of one or more preventive strategies to improve knowledge regarding VAP [10]. Similarly, Gatell, et al. did a prospective study and reported improvement in both knowledge and compliance with VAP preventive measures after training session among nurses [16]. An observational study conducted by Rello J, et al. concluded that educational programs can reduce the chance of VAP. Thus, nurses working in intensive care units must be educated regarding VAP prevention strategies [17]. Study results of Al-Khader, et al. revealed that the practice level of participants (42.5\%) was fair, $32.5 \%$ had poor and $2.5 \%$ of them had good practice level [10]. The results were similar to present study findings showing majority $(53 \%)$ of samples were having Average scores in Pre-test.

The present study found that there is no significant association of knowledge and practice scores with selected demographic variables. Similar findings were reported by Ghimire S, et al. showing no statistically significant association between respondents' level of knowledge regarding the prevention of VAP with working experience ( $p-0.493)$ and qualification ( $p-0.459)$ [18]. In contrast study findings of Baby $N$ [19] revealed that there was a significant association between the knowledge score with demographic variables like age, religion and marital status at the level of $p<0.05$. 


\section{Limitations}

The study was limited to a single set-up, without a control group and small sample size that limits the generalization of present study findings.

\section{Conclusion}

The present study found that there was a noticeable increase in knowledge and practice score in post-test after implementation of structured teaching program as compared to pre-test score, indicating the effectiveness of structured teaching Program on care bundle regarding the prevention of ventilator-associated pneumonia.

\section{Conflict of Interest}

None.

\section{Funding}

None.

\section{References}

1. Timsit JF, Esaied W, Neuville M, Bouadma L, Mourvllier B (2017) Update on ventilator-associated pneumonia. F1000Res 6: 2061.

2. Barbier F, Andremont A, Wolff M, Bouadma L (2013) Hospital-acquired pneumonia and ventilator-associated pneumonia: Recent advances in epidemiology and management. Curr Opin Pulm Med 19: 216-228.

3. Bouadma L, Sonneville R, Garrouste OM, Darmon M, Souweine B, et al. (2015) Ventilator-associated events: Prevalence, outcome, and relationship with ventilator-associated pneumonia. Crit Care Med 43: 1798-1806.

4. Marcos I Restrepo, Janet Peterson, Juan F Fernandez, Zhihai Qin, Alan C Fisher, et al. (2013) Comparison of the bacterial etiology of early-onset and late-onset ventilator-associated pneumonia in subjects enrolled in 2 large clinical studies. Respir Care 58: 1220-1225.

5. Benítez L, Ricart M (2005) Pathogenesis and environmental factors in ventilator-associated pneumonia. Enferm Infecc Microbiol Clin 23: 10-17.

6. Institute for Healthcare Improvement (2020) Bundle up for safety.

7. Wip C, Napolitano L (2009) Bundles to prevent ventilator-associated pneumonia: How valuable are they? Curr Opin Infect Dis 22: 159-166.
8. Khaled M Al-Sayaghi (2014) Prevention of ventilator-associated pneumonia: A knowledge survey among intensive care nurses in Yemen. Saudi Med J 35: 269-276.

9. Aziz Z, Kausar S, Zahid S, Farooqi S, Aziz Z, et al. (2020) Knowledge and practice of ventilator care bundle for preventing ventilator associated pneumonia by ICU nurses of tertiary care hospitals of Lahore. Anaesth Pain Intensive Care 24: 426-434.

10. Al Shameri FA (2017) Critical care nurse's knowledge of ventilator-associated pneumonia prevention in selected hospitals, Khartoum. Nurs Health Care Int J 1: 000128.

11. Chithra RA, Raju J (2017) Effect of structured teaching program on knowledge regarding prevention of ventilator associated pneumonia among critical care nurses. Int $\mathrm{J}$ Health Sci Res 7: 156-163.

12. Alp E, Voss A (2006) Ventilator associated pneumonia and infection control. Ann Clin Microbiol Antimicrob 5: 7.

13. Kalanuria AA, Zai W, Mirski M (2014) Ventilator-associated pneumonia in the ICU. Crit Care 18: 208.

14. Monegro AF, Muppidi V, Regunath H (2020) Hospital acquired infections. In: StatPearls. StatPearls Publishing, Treasure Island (FL).

15. Busi S, Ramanjamma K (2016) Effectiveness of structured teaching Program on level of knowledge and practices regarding prevention of ventilator associated pneumonia among critical care nurses of NRI General Hospital, Guntur, A.P., India. Int J Adv Nur Management 4: 125-129.

16. Jam Gatell MR, Sante Roig M, Hernandez Vian O, Carrillo Santín E, Turégano Duaso C, et al. (2012) Assessment of a training programme for the prevention of ventilator-associated pneumonia. Nurs Crit Care 17: 285-292.

17. Rello J, Lorente C, Bodi M, Diaz E, Ricart M, et al. (2002) Why do physicians not follow evidence-based guidelines for preventing ventilator-associated pneumonia? A survey based on the opinions of an international panel of intensivists. Chest 122: 656-661.

18. Ghimire S, Neupane S (2018) Knowledge regarding prevention of ventilator associated pneumonia among nurses in a tertiary hospital, Rupandehi, Nepal. Journal of Universal College of Medical Sciences 6: 27-31.

19. Baby N (2012) A study to assess the knowledge and practice of documentation techniques among staff nurses in selected hospitals, at davangere with a view to develop an information booklet. Rajiv Gandhi University of Health Sciences, Karnataka, India. 